\title{
Micellar Liquid Chromatographic Determination of Idrocilamide in Dosage Form and Biological Fluids: Application to Stability Study
}

\author{
Fathalla Belal*, Manal Eid, Amina EL-Brashy and Wael Talaat
}

Department of Analytical Chemistry, Faculty of Pharmacy, University of Mansoura, Mansoura 35516, Egypt

\begin{abstract}
A simple, stability-indicating, reversed phase high perfomance liquid chromatographic method was developed and validated for the determination of idrocilamide in the presence of its degradation products .The separation was conducted using A Hibar $\mathrm{C}_{18}(150 \times 4.6 \mathrm{~mm}$ i.d $)$ stainless steel column at ambient temperature with UV detection at $277 \mathrm{~nm}$. Micellar mobile phase consisted of $0.1 \mathrm{M}$ sodium dodecyl sulphate, $10 \% \mathrm{n}$-propanol, $0.3 \%$ triethylamine in $0.02 \mathrm{M}$ phosphoric acid $(\mathrm{pH}$ 6) was used and pumped at a flow rate of $1 \mathrm{~mL} / \mathrm{min}$. The calibration curve was rectilinear over the concentration range of $1-10 \mu \mathrm{g} / \mathrm{mL}$ with a detection limit of $0.1 \mu \mathrm{g} / \mathrm{mL}$ and quantification limit of $0.3 \mu \mathrm{g} / \mathrm{mL}$. The proposed method was successfully applied to the analysis of idrocilamide in commercial cream with mean \% recovery of $100.74 \pm 0.93$. The method was extended to the in-vitro determination of idrocilamide in spiked human plasma and urine samples with mean \% recoveries of $99.93 \pm 0.31$ and $100.1 \pm 0.26$ respectively Moreover, the method was utilized to investigate the kinetics of both acid and alkaline induced degradation of the drug. The apparent first -order rate constant, half life time and activation energies of the degradation reactions were calculated
\end{abstract}

Keywords: Human plasma; Urine samples; Idrocilamide; Mobile phase

\section{Introduction}

Idrocilamide is $\mathrm{N}$-(2-hydroxyethyl)cinmamamide [1]. It is used as central muscle relaxant when given by mouth or intramuscular. It is reported to have local muscle relaxant and anti- inflammatory effects; and is now mainly used topically [2]. The literature is poor in the reported methods for the analysis of idrocilamide. Only two HPLC methods were reported for its determination, one using $60 \%$ methanol [3] and the other $65 \%$ methanol [4] as mobile phases. Two Stability -indicating methods were also developed for its determination $[5,6]$. HPTLC and HPLC methods were introduced for determination of idrocilamide in presence of its degradation products [5]. The second method is based on the use of first derivative spectrophotometry for the analysis in tablets. This fact motivated us to develop a simple and reliable method for its determination in dosage form and biological fluids. Micellar liquid chromatography (MLC) has proved to be a useful technique in the determination of diverse groups of compounds in several matrices including food samples. MLC allows complex matrices to be analysed without the aid of extraction and with direct injection of the samples. Micelles tend to bind proteins competitively, thereby releasing protein-bound drugs and proteins, rather than precipitating into the column. Proteins compounds are solubilized and washed harmlessly away, eluting with the solvent front. MLC generate less amount of toxic waste in comparison to aqueous-organic solvents, so that they are less toxic, non-flammable, biodegradable and relatively inexpensive [7]. Micelles provide hydrophobic and electrostatic (for ionic surfactants) sites of interaction. In the micelles, three sites of solubilisation can be identified: the core (hydrophobic), the surface (hydrophilic) and the palisade layer (the region between the surfactant head groups and the core). Solutes associated to micelles experience a microenvironment that is different from that of bulk solvent. This is reflected by micelle-induced perturbations in solute physicochemical properties, including changes in solubility, acidity, photophysical properties, and reaction rates [8]. It has also other advantages like using small amounts of organic modifier which is retained in the micellar solution of SDS, thus reducing the risk of evaporation and make the micellar mobile phase more stable. Also, the capability of simultaneous separation of hydrophobic and hydrophilic analytes in the same run without a gradient elution [9]. Unfortunately, some drawbacks were reported concerning the chromtographic efficiency and weak elution strength of pure micellar solution [10,11]. Many articles has been reported for determination of drugs in pharmaceutical preparations and biological fluids [12-14]. In our laboratory, MLC proved to be a useful technique in the quality control of several drugs in pharmaceutical preparations using hybrid micellar mobile phase containing SDS and organic modifier [15-17]. The proposed method is superior over the reported methods in the ease of biological fluids analysis where direct injection of plasma and urine is investigated.

\section{Experimental}

\section{Reagents}

All chemicals used were of Analytical Reagents grade, and the solvents were of HPLC grade.

- $\quad$ Orhtophosphoric acid (Prolabo, Paris, France).

- Methanol (Hipersolv, Merck).

- $\quad$ Sodium dodecyl sulphate (Park Scientific limited, Northompthon, UK) $0.1 \mathrm{M}$ aquous solution was prepared.

- $\mathrm{n}$ - Propanol, Ethanol and Triethylamine (Riedel- ole Haen, Sleeze, Germany).

*Corresponding author: Fathalla Belal, Department of Analytical Chemistry Faculty of Pharmacy, University of Mansoura, Mansoura 35516, Egypt, Tel: +966 1 4677348, E-mail: ffbelal@yahoo.com

Received December 12, 2014; Accepted January 27, 2015; Published February 02, 2015

Citation: Belal F, Eid M, EL-Brashy A, Talaat W (2015) Micellar Liquid Chromatographic Determination of Idrocilamide in Dosage Form and Biological Fluids:Application to Stability Study. Pharm Anal Acta 6: 335. doi: 10.4172/2153-2435.1000335

Copyright: (c) 2015 Belal F, et al. This is an open-access article distributed under the terms of the Creative Commons Attribution License, which permits unrestricted use, distribution, and reproduction in any medium, provided the original author and source are credited. 
- $\quad$ n- Butanol (Honi limited, London, UK).

\section{Materials}

1) Idrocilamide was kindly supplied by Minapharm Pharmaceuticals, $10^{\text {th }}$ of Ramadan city, Egypt. The purity of the drug was established by applying the comparison method [3] and was found to be $99.88 \pm 0.41$

2) Srilane $e^{\circledast}$ cream $5 \%$ (Minapharm Pharmaceuticals) was obtained from the local market (Batch number B5468).

3) Plasma was obtained from Mansoura University Hospital and was kept frozen untill use after gentle thawing.

4) Urine samples were obtained from healthy volunteer (male 27 years old).

\section{Instrument}

- $\quad$ Separation was performed using a Perkin Elmer ${ }^{\mathrm{tm}}$ Series 200 Chromatograph equipped with a Rheodyne injector valve with $20 \mu \mathrm{L}$ loop and a UV/VIS detector set at $277 \mathrm{~nm}$ Total Chrom Workstation was applied for data collection and processing ( MA, USA )

- A Shimadzu UV 1601 PC Spectrophotometer equipped with a pair of $1 \mathrm{~cm}$ matched quartz cells. Recording range: $0-2$, wavelength $277 \mathrm{~nm}$; factor : 1 ; number of cells : 1 ; cycle time: $0.1 \mathrm{~min}$.

\section{Column and mobile phase}

EC 150/406 Hibar 100-5 $\mathrm{C}_{18}$ column was used. The components of the micellar mobile phase was $0.1 \mathrm{M}$ sodium dodecyl sulphate (SDS), $10 \% \mathrm{n}$-propanol and $0.3 \%$ triethyl amine in $0.02 \mathrm{M}$ phosphoric acid (pH 6). The mixture was then shaken using an ultrasonic bath for 30 min. The resulting transparent mobile phase was filtered through a 0.45 $\mu \mathrm{m}$ membrane filter (Millipore, Ireland). The micellar mobile phase was freshly prepared. The column hold up value was the first deviation of the base line obtained.

\section{Standard solutions}

Stock solution of idrocilamide was prepared by dissolving $10.0 \mathrm{mg}$ of the drug in few $\mathrm{mL}$ of methanol then diluted with distilled water to $25.0 \mathrm{~mL}$ in a $25 \mathrm{~mL}$ volumetric flask. The stock solution

was further diluted with the mobile phase to obtain the working concentration range $(1-10 \mu \mathrm{g} / \mathrm{mL})$. The stock solution was found to be stable for at least one week when kept in the refrigerator .

\section{General procedures}

Construction of calibration graph: Aliquots of the working solution were transferred into a series of $10 \mathrm{ml}$ volumetric flasks and diluted with the mobile phase to the mark so that the concentration of these solutions was in range of $1-10 \mu \mathrm{g} / \mathrm{ml}, 20 \mu \mathrm{L}$ aliquots were injected (triplicate) and eluted with the mobile phase. A plot of the peak area versus concentration of the drug was constructed to obtain the standard calibration curve .Alternatively, the regression equation was derived.

Acidic and Alkaline degradation of idrocilamide. Aliquot volumes of idrocilamide standard solution were mixed with $5 \mathrm{~mL}$ of either $2 \mathrm{M}$ $\mathrm{NaOH}$ or $1 \mathrm{M} \mathrm{HCl}$, the solutions were heated at different temperature settings $60,70,80,90,100^{\circ} \mathrm{C}$ using a thermostatically controlled water bath for different time intervals 5,15,25,35,45 minutes then allowed to cool. The solutions were neutralized to $\mathrm{pH} 7$ using $2 \mathrm{M} \mathrm{HCl}$ or 1 $\mathrm{M} \mathrm{NaOH}$ respectively. Then aliquot volumes of these solutions were transferred to $10 \mathrm{~mL}$ volumetric flasks so that the final concentration was within the working concentration range and treated as described under "Construction of the calibration graph". Complete degradation was tested by the disappearance of HPLC peak of the parent drug.

Analysis of Idrocilamide in cream: The contents of five tubes were mixed and an amount of the cream equivalent to $0.05 \mathrm{~g}$ of idrocilamide was accurately weighed and extracted with methanol, filtered and diluted with the same solvent to the mark in a $100 \mathrm{~mL}$ volumetric flask. This solution was serially diluted with the mobile phase to get the working concentration range in a series of $10 \mathrm{~mL}$ volumetric flasks. $20 \mu \mathrm{L}$ were injected (triplicate) and eluted with the mobile phase. The nominal content was obtained either from the calibration graph or using the regression equation.

\section{Analysis of idrocilamide in spiked plasma and urine}

$1.0 \mathrm{~mL}$ aliquots of sample plasma or urine were transferred into a series of centrifuge tubes, spiked with increasing concentrations of idrocilamide to obtain the working concentration 1-10 $\mu \mathrm{g} / \mathrm{mL} .20 \mu \mathrm{L}$ were injected (triplicate) directly without extraction and eluted with the micellar mobile phase. The nominal concentration was obtained from the corresponding regression equation.

\section{Results and Discussion}

The acid and alkaline degradation of idrocilamide was found to give one and the same degradation product. In both cases the amide group being hydrolysed yielding the same reaction products cinnamic acid and hydroxyl amine. The latter is non- UV absorbing, therefore in both cases, only one peak of the degradation product appears. The peaks of the drug and its degradation product are well separated from each other (resolution factor Rs=2.4) and the retention times were 1.5 and 3.2 for cinnamic acid (CA) and idrocilamide respectively.

\section{UV Detection}

The UV absorption spectrum of idrocilamide was scanned and the $\lambda_{\max } 277$ was selected for detection of peaks (Figure 2 shows the spectra of idrocilamide before and after degradation).

\section{Study of the Experimental parameters}

The experimental parameters affecting the chromatographic separation of the drug and cinnamic acid (CA) including mobile phase, flow rate and linearity range were studied to determine the optimum conditions for the assay procedure. Variables were optimized by changing each in turn, while keeping all others constant to obtain the highest resolution.

\section{Mobile phase}

A micellar mobile phase has been utilized in this study for the separation of idrocilamide and cinnamic acid. Several modifications in micellar mobile phase composition were studied. These modifications included change of the $\mathrm{pH}$, the concentration of surfactant and type and concentration of co- surfactant.

\section{pH}

The $\mathrm{pH}$ was changed using increasing volumes of triethyl amine or phosphoric acid. The best $\mathrm{pH}$ was found to be 6.0 as it gave the highest number of theoritical plates (Table 1).

\section{The concentration of surfactant}

The effect of SDS concentration on retention time and detector response (as peak area) was investigated using mobile phases containing 


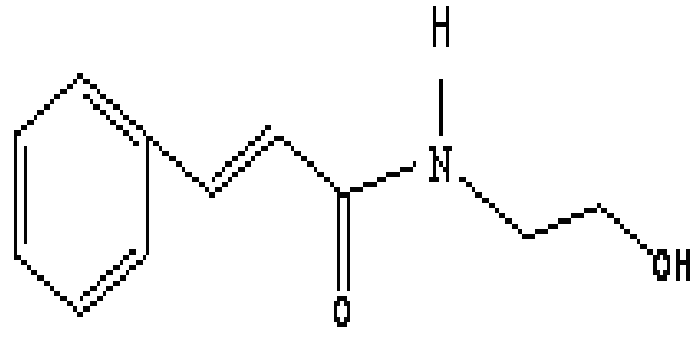

Figure 1: Structural formula of idrocilamide

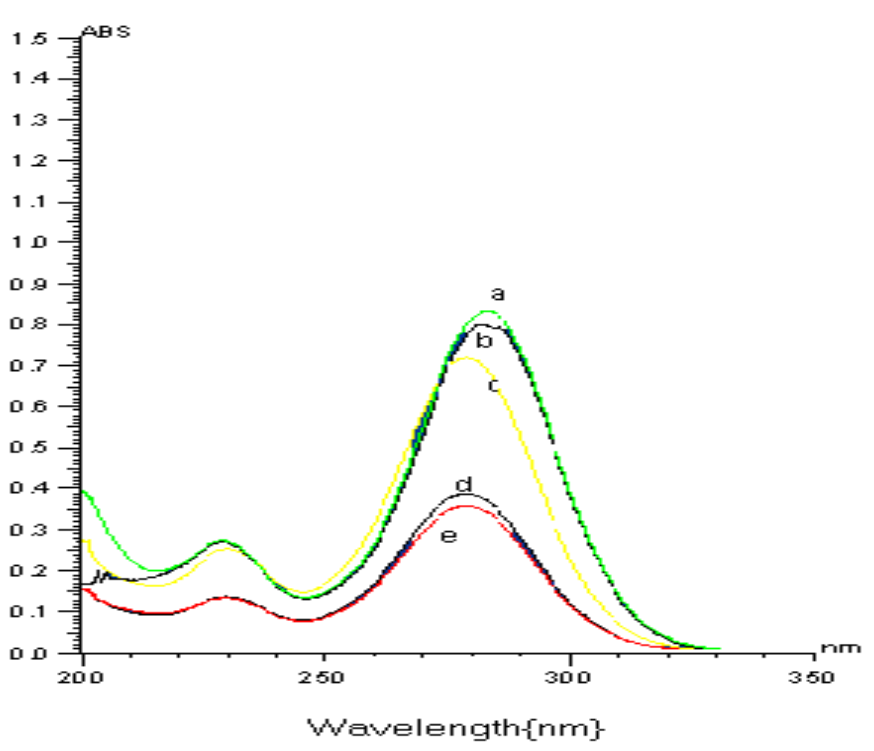

Figure 2: Spectra of idrocilamide $(5 \mu \mathrm{g} / \mathrm{mL})$ before and after degradation a)Spectrum of idrocilamide in $2 \mathrm{M} \mathrm{NaOH}$ on cold

b) Spectrum of idrocilamide in methanol/water

c) Spectrum of idrocilamide in $1 \mathrm{M} \mathrm{HCl}$

d)Spectrum of idrocilamide in $2 \mathrm{M} \mathrm{NaOH}$ after degradation $\left(100^{\circ} \mathrm{C}\right.$ for 45 $\min )$.

e)Spectrum of idrocilamide in $1 \mathrm{M} \mathrm{HCl}$ after degradation $\left(100^{\circ} \mathrm{C}\right.$ for $45 \mathrm{~min}$ ).

SDS concentrations ranging from 0.05 to $0.15 \mathrm{M}$. It was found that, the increase in the concentration of SDS decreased the retention time of both the drug and its degradation product all over the investigated range. Meanwhile, increasing SDS concentration increased the number of theoretical plates of the drug and its degradation product up to 0.1 $\mathrm{M}$, further increase in SDS concentration up to $0.15 \mathrm{M}$ reduced the number of theoretical plates of the drug and its degradation product (Table 1) Therefore $0.1 \mathrm{M}$ concentration of SDS was used in the study.

\section{The effect of co-surfactant}

$10 \%$ Propanol was replaced with either methanol, ethanol, $\mathrm{n}$ - butanol, in an attempt to study the effect of the nature of the co surfactant on the selectivity of the method. The four co-surfactants were found to be equally useful for separation. The number of theoretical plates given as a function of the co-surfactants investigated (Table 1 ). The concentration of the co- surfactant was investigated using different concentrations within the range of 5-15\%. The retention time decreased with increasing the concentration. A concentration of $10 \%$ was found to be suitable as it gave the highest number of theoretical plates (Table 1).

\section{Flow rate}

The effect of flow rate on the column efficiency for the separation of the studied drug and its degradation product was studied. The flow rate was changed over the range of $0.5-2 \mathrm{~mL} / \mathrm{min}$ A flow rate of $1 \mathrm{~mL} /$ min was optimal for a good separation (Table 1).

\section{Specificity}

Attempts were made to degrade idrocilamide samples by different ways to assess the stability indicating nature of the method .Solutions of $0.1 \mathrm{mg} / \mathrm{mL}$ idrocilamide were prepared in methanol. In both alkaline and acidic media, idrocilamide gave one degradation product with the same retention time at $1.5 \mathrm{~min}$.

\section{Analytical validation}

Linearity of the method: After optimizing the conditions, it was found that the peak area and the final concentration was linear over the range $1-10 \mu \mathrm{g} / \mathrm{ml}$. Linear regression analysis of results gave the following equation:

$$
\text { P.A }=13.57+3080 \mathrm{C} \quad \mathrm{r}=0.9999
$$

Where P.A= Peak area

$\mathrm{C}=$ concentration in $\mu \mathrm{g} / \mathrm{mL}$

$\mathrm{r}=$ correlation coefficient

The results of the statistical analysis of experimental data for pure samples, such as standard deviation of the slope $\left(\mathrm{s}_{\mathrm{b}}\right)$ and standard deviation of intercept $\left(\mathrm{s}_{\mathrm{a}}\right)$ and the standard deviation of residuals $(\mathrm{Sy} / \mathrm{x})$ were found to be $0.7,4.1,4.8$ respectively.

\section{Accuracy and precision}

The proposed method was evaluated by studying the accuracy as percent relative error (\%Er) and precision as percent relative standard deviation (\% RSD) [18] The results of intraday and interday accuracy and precision for the method are summarized in Table 2.

\section{Limits of detection and quantification}

The limit of detection (LOD) was calculated from the calibration curve according to the formula $L O D=3.3 \mathrm{~S}_{\mathrm{a}} / \mathrm{b}[18]$, with Sa being the standard deviation of the intercept of the regression line, $b$ being the slope of the calibration curve. The limit of quantification, defined here as $L O Q=10 \mathrm{~S}_{\mathrm{a}} / \mathrm{b}$ were determined on the basis of standard deviation of response and slope.

\section{Application to cream}

The proposed method was successfully applied for the determination of idrocilamide in cream. The average percentage recovery was 100.74 \pm 0.93 . The results shown in Table 3 are in good agreement with those obtained by the comparison method [3].The latter involves the use of column $(20 \mathrm{~cm} \times 5 \mathrm{~mm})$ of octadecylsilane (ODS) with a mobile phase consists of aqueous $60 \%$ methanol with flow rate of $1 \mathrm{~mL} / \mathrm{min}$. and detection at $280 \mathrm{~nm}$. The proposed method is fairly sensitive since it can measure down to $1.0 \mu \mathrm{g} / \mathrm{mL}$. The comparison method is linear over the range $4-16 \mu \mathrm{g} / \mathrm{ml}$.

\section{Application to biological fluids}

The high sensitivity attained by the proposed method allows determination of idrocilamide in biological fluids without extraction Figure 3. The reported maximum plasma concentration was 2.58 $\mu \mathrm{g} / \mathrm{ml}[19]$. Table 4 shows the results of recovery studies from the corresponding calibration curve for spiked plasma and urine. 
Citation: Belal F, Eid M, EL-Brashy A, Talaat W (2015) Micellar Liquid Chromatographic Determination of Idrocilamide in Dosage Form and Biological Fluids:Application to Stability Study. Pharm Anal Acta 6: 335. doi:10.4172/2153-2435.1000335

Page 4 of 7

\begin{tabular}{|c|c|c|c|c|c|c|}
\hline \multicolumn{2}{|c|}{ Experimental Parameters } & $N_{1}$ & $\mathrm{~N}_{2}$ & $\mathrm{~K}_{1}^{\prime}$ & $\mathrm{K}_{2}^{\prime}$ & $\alpha$ \\
\hline \multirow{9}{*}{$\mathrm{pH}$} & 3 & 1115 & 991 & 2.1 & 0.45 & 4.7 \\
\hline & 3.5 & 1775 & 1100 & 2.5 & 0.41 & 6.1 \\
\hline & 4 & 1994 & 1172 & 2.21 & 0.5 & 4.42 \\
\hline & 4.5 & 1226 & 1180 & 2.6 & 0.51 & 5.2 \\
\hline & 5 & 2259 & 1215 & 2.44 & 0.51 & 5.1 \\
\hline & 5.5 & 2366 & 1246 & 2.55 & 0.52 & 4.7 \\
\hline & 6 & 2444 & 1250 & 2.44 & 0.52 & 4.7 \\
\hline & 6.5 & 1354 & 1190 & 2.15 & 0.51 & 4.2 \\
\hline & 7 & 1268 & 1115 & 1.5 & 0.51 & 3.1 \\
\hline \multirow{5}{*}{$\begin{array}{l}\text { SDS conc. } \\
\text { (Mole/L) }\end{array}$} & 0.05 & 1443 & 1240 & 3.5 & 0.9 & 3.11 \\
\hline & 0.08 & 2366 & 1246 & 2.55 & 0.52 & 4.7 \\
\hline & 0.1 & 2444 & 1250 & 2.2 & 0.42 & 5.2 \\
\hline & 0.12 & 1665 & 1120 & 1.8 & 0.38 & 4.7 \\
\hline & 0.15 & 1323 & 1028 & 1.5 & 0.3 & 5 \\
\hline \multirow{4}{*}{ Type of co-Surfactant. } & Methanol & 1804 & 1185 & 2.33 & 0.48 & 4.9 \\
\hline & Ethanol & 1999 & 1230 & 2.35 & 0.5 & 4.7 \\
\hline & n-Propanol & 2366 & 1246 & 2.55 & 0.52 & 4.7 \\
\hline & n-Butanol & 1745 & 1200 & 2.41 & 0.52 & 4.6 \\
\hline \multirow{5}{*}{ Conc. of propanol } & $6 \%$ & 2106 & 1233 & 2.8 & 0.8 & 3.2 \\
\hline & $8 \%$ & 2366 & 1246 & 2.55 & 0.52 & 4.7 \\
\hline & $10 \%$ & 2444 & 2250 & 2.3 & 0.4 & 5.75 \\
\hline & $12 \%$ & 2038 & 1170 & 1.86 & 0.35 & 5.3 \\
\hline & $15 \%$ & 1462 & 1030 & 1.6 & 0.3 & 5.33 \\
\hline \multirow{5}{*}{$\begin{array}{l}\text { Flow rate } \\
\text { (ml/min) }\end{array}$} & 0.5 & 2138 & 980 & 5.74 & 2 & 2.8 \\
\hline & 0.8 & 2285 & 1190 & 4.1 & 1.5 & 2.73 \\
\hline & 1 & 2444 & 1250 & 2.55 & 0.52 & 4.7 \\
\hline & 1.2 & 1816 & 1200 & 2 & 0.35 & 5.71 \\
\hline & 1.5 & 1998 & 1140 & 1.56 & 0.23 & 6.8 \\
\hline
\end{tabular}

$\mathrm{N} 1, \mathrm{~N} 2$ :The number of theoretical plates of cinnamic acid and idrocilamide

$\mathrm{K}_{1}^{\prime}, \mathrm{K}_{2}^{\prime}$ : The capacity factors of cinnamic acid and idrocilamide

$\alpha$ : The selectivity factor

Table 1: Effect of different experimental parameters on the column efficiency for the separation of idrocilamide and its degradation product

\begin{tabular}{|c|c|c|c|c|}
\hline Conc.added $\mu \mathrm{g} / \mathrm{mL}$ & $\begin{array}{l}\text { Conc.found } \\
(\mu \mathrm{g} / \mathrm{mL})\end{array}$ & $\%$ Found & $\%$ RSD & $\% \mathrm{Er}$ \\
\hline \multicolumn{5}{|l|}{ Intraday } \\
\hline 1 & 0.998 & $99.81 \pm 0.10$ & 0.1 & 0.058 \\
\hline 5 & 4.9895 & $99.79 \pm 0.12$ & 0.12 & 0.069 \\
\hline 10 & 9.996 & $99.96 \pm 0.10$ & 0.1 & 0.058 \\
\hline \multicolumn{5}{|l|}{ Interday } \\
\hline 1 & 1.01 & $100.10 \pm 0.26$ & 0.26 & 0.15 \\
\hline 5 & 4.995 & $99.90 \pm 0.30$ & 0.3 & 0.17 \\
\hline 10 & 10.02 & $100.2 \pm 0.2$ & 0.2 & 0.11 \\
\hline
\end{tabular}

Each result is the average of three separation determinations

Table 2: Intraday and inter day precision for the proposed method

\begin{tabular}{|c|c|c|c|c|c|}
\hline \multirow{2}{*}{ Preparation } & \multicolumn{3}{|c|}{ Proposed method } & \multicolumn{2}{|c|}{ Comparison method ${ }^{(3)}$} \\
\hline & Amount taken, $\mu \mathrm{g} / \mathrm{mL}$ & Amount found, $\mu \mathrm{g} / \mathrm{mL}$ & $\%$ Found $^{*}$ & Amount taken, $\mu \mathrm{g} / \mathrm{mL}$ & $\%$ Found* \\
\hline 1)Srelane cream $5 \%$ & 1 & 0.995 & 99.5 & 4 & 99.2 \\
\hline & 3 & 3.012 & 100.4 & 8 & 99.1 \\
\hline & 7 & 6.937 & 99.1 & 12 & 99.8 \\
\hline & 10 & 10.03 & 100.3 & 16 & 100.1 \\
\hline Mean $\pm S D$ & & & $99.83 \pm 0.40$ & & $99.60 \pm 0.48$ \\
\hline t-test & & 0.74 & $(2.45)^{\star \star}$ & & \\
\hline F-test & & 1.44 & $(9.277)^{\star \star}$ & & \\
\hline
\end{tabular}

Minapharm pharmaceuticals, Cairo,Egypt,batch No.6CE0246

Table 3: Application of the proposed and comparison methods to determination of idrocilamide in commercial cream 
Citation: Belal F, Eid M, EL-Brashy A, Talaat W (2015) Micellar Liquid Chromatographic Determination of Idrocilamide in Dosage Form and Biological Fluids:Application to Stability Study. Pharm Anal Acta 6: 335. doi:10.4172/2153-2435.1000335

Page 5 of 7

\begin{tabular}{|c|c|c|c|c|c|}
\hline \multirow{2}{*}{ Sample } & \multicolumn{3}{|c|}{ Proposed method } & \multicolumn{2}{|c|}{ Comparison method [3] } \\
\hline & Amount added, $\mu \mathrm{g} / \mathrm{mL}$ & Amount found, $\mu \mathrm{g} / \mathrm{mL}$ & \% Recovery & Amount added, $\mu \mathrm{g} / \mathrm{mL}$ & $\%$ Recovery \\
\hline \multirow{3}{*}{ 1) Plasma } & 1 & 1 & 100 & 4 & 100 \\
\hline & 5 & 5.01 & 100.2 & 8 & 100.5 \\
\hline & 10 & 9.96 & 99.6 & 12 & 99.14 \\
\hline Mean $\pm S D$ & & & $99.93 \pm 0.31$ & & $99.88 \pm 0.69$ \\
\hline t-test & & 0.26 & $(2.132)^{\star *}$ & & \\
\hline F-test & & 4.95 & $(19.00)^{\star *}$ & & \\
\hline \multirow[t]{3}{*}{ 2) Urine } & 1 & 1 & 100 & 4 & 100 \\
\hline & 5 & 5.02 & 100.4 & 8 & 99.9 \\
\hline & 10 & 9.99 & 99.9 & 12 & 100.7 \\
\hline Mean $\pm S D$ & & & $100.10 \pm 0.26$ & & $100.20 \pm 0.44$ \\
\hline t-test & & 1.15 & $(2.132)^{\star *}$ & & \\
\hline F-test & & 2.86 & $(19.00)^{\star *}$ & & \\
\hline
\end{tabular}

** The value of tabulated $t$ and $F,(\text { at } p=0.05)^{(13)}$

Table 4: Determination of idrocilamide in biological fluids by the proposed and comparison methods

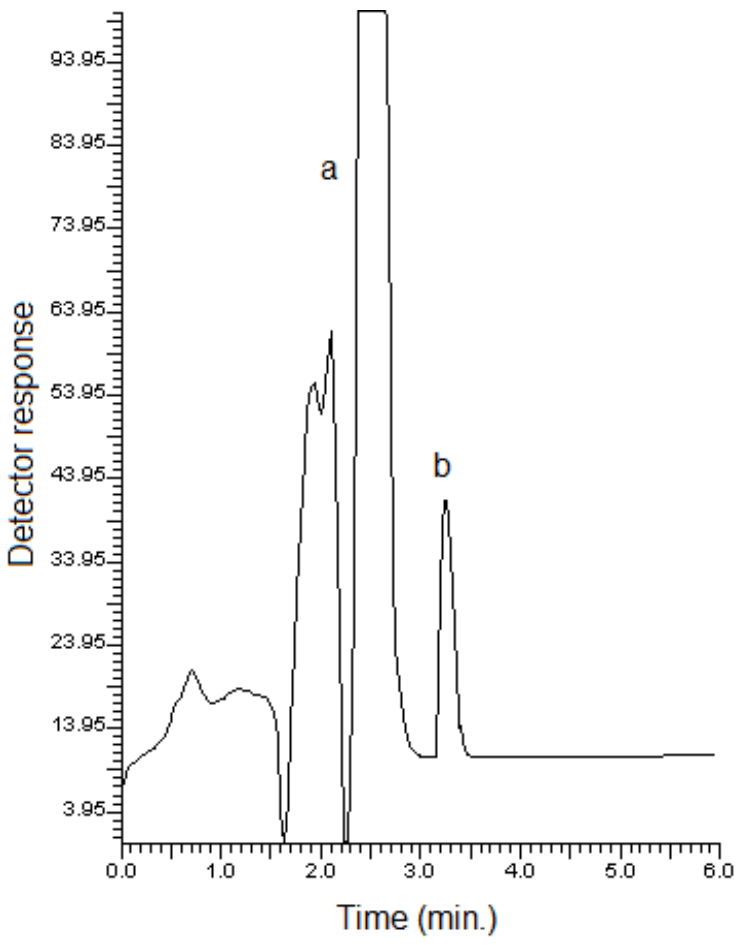

a: Plasma peak

b: idrocilamide

Figure 3: Chromatogram of idrocilamide $(5 \mu \mathrm{g} / \mathrm{mL})$ in spiked plasma

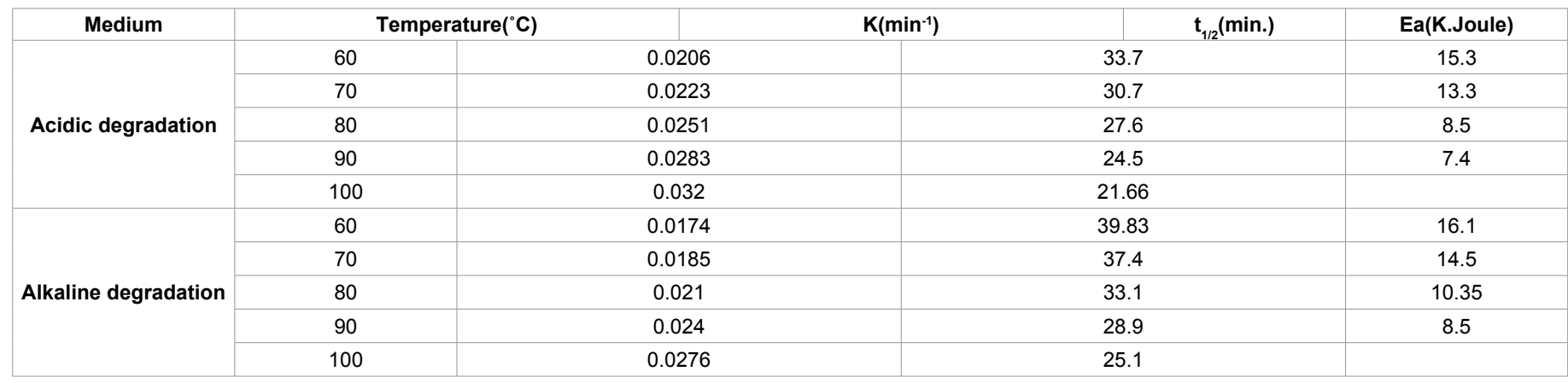

Table 5: Degradation rate constant $(K)$ and half life time $\left(t_{1 / 2}\right)$ for idrocilamide 


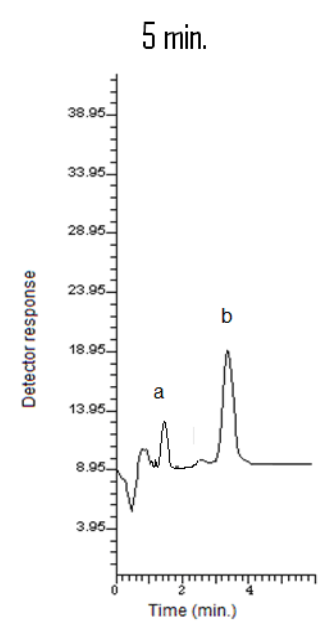

$35 \mathrm{mim}$.

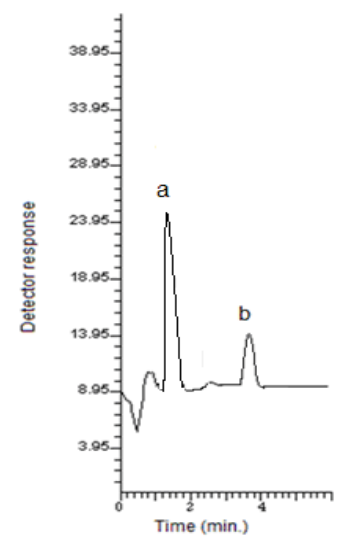

$15 \mathrm{~min}$.

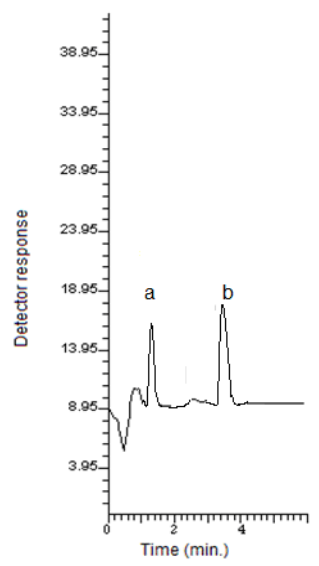

$25 \mathrm{~min}$.

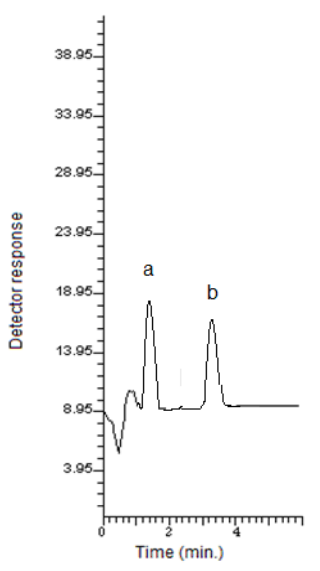

$45 \mathrm{~min}$.

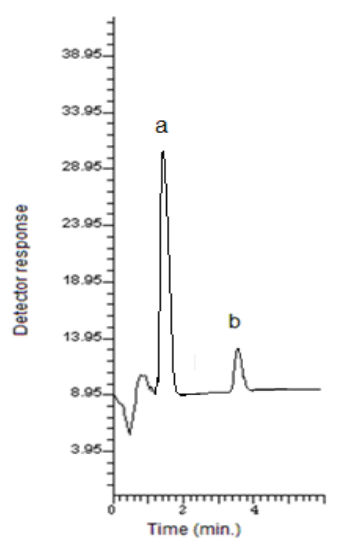

$35 \mathrm{mim}$.

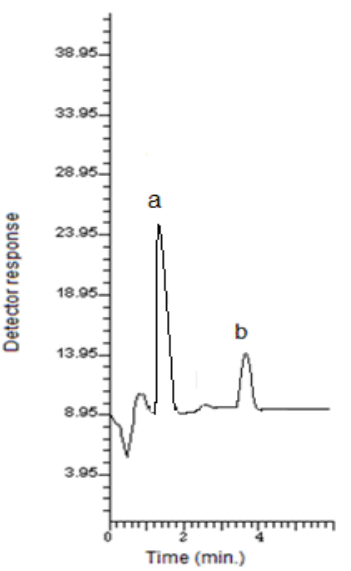

$35 \mathrm{mim}$.

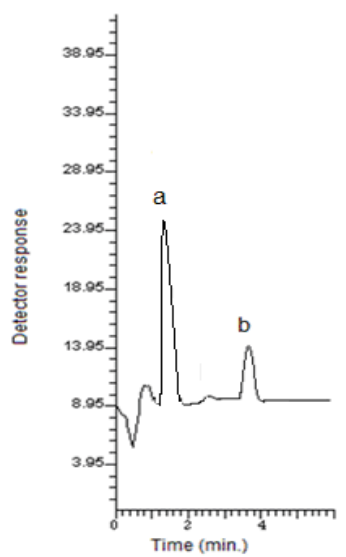

$45 \mathrm{~min}$.

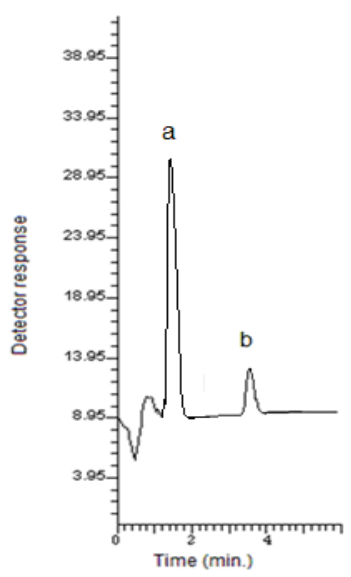

$45 \mathrm{~min}$.

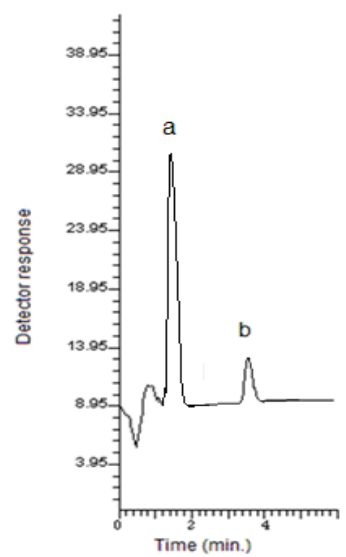

a)degradation product

b)Idrocilamide $(5 \mu \mathrm{g} / \mathrm{mL})$

using mobile phase consisting of $0.1 \mathrm{M} \mathrm{SDS}, 10 \%$ propanol and $0.3 \%$ triethyl amine and $0.02 \mathrm{M}$ phosphoric acid (pH 6 ) with UV detection at $277 \mathrm{~nm}$. Figure 4: Chromatogram showing the degradation of idrocilamide at $100^{\circ} \mathrm{C}$ for different time intervals.

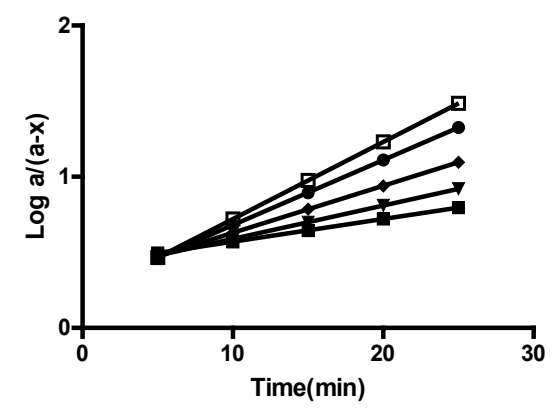

a $Y=0.42+8.94 \times 10^{-3} t$

$\checkmark=0.36+9.7 \times 10^{-3} \mathrm{t}$

- $Y=0.32+0.011 \mathrm{t}$

- $Y=0.24+0.0123 t$

ㅁ $Y=0.22+0.014 t$

$\left(60^{\circ} \mathrm{C}\right) \mathrm{r}=0.997$

$\left(70{ }^{\circ} \mathrm{C}\right) \mathrm{r}=0.997$

$\left(80^{\circ} \mathrm{C}\right) \mathrm{r}=0.998$

$\left(90^{\circ} \mathrm{C}\right) \mathrm{r}=0.998$

$\left(100^{\circ} \mathrm{C}\right) \mathrm{r}=0.998$

Figure 5: Semilogarithmic plot of the amount remaining of idrocilamide $5 \mu \mathrm{g} / \mathrm{mL}$ versus different heating times

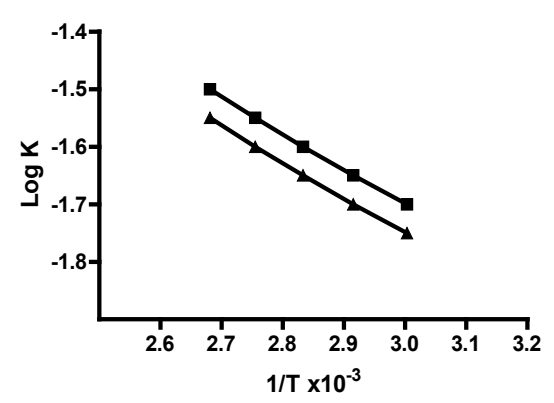

\section{$\rightarrow$ Arrhenius plot of acidic degradation $Y=-0.45-7011 / T$ \\ - Arrhenius plot of alkaline degradation $Y=-0.33-770.31 / T$}

Figure 6: Arrhenius plot for the degradation of idrocilamide 


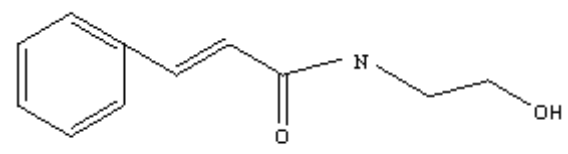

idrocilaride

$\mathrm{HCl}$

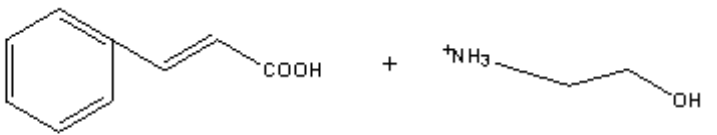

3a:Proposal of the acidic deg radation reaction

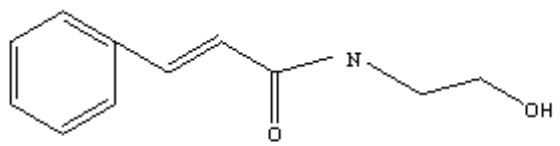

$\mathrm{NaOH}$

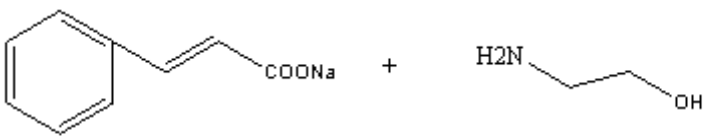

$3 b:$ Proposal of the alkaline degradation reaction

Figure 7: Proposal scheme of the degradation reaction of idrocilamide in both acid and alkaline media

\section{Degradation kinetics}

Figure 4 shows the chromatogram of idrocilamide after being subjected to degradation. The degradation was found to be temperature dependent (Figure 4). At the selected temperatures settings $\left(60-100^{\circ} \mathrm{C}\right)$, the degradation followed pseudo-first order kinetics (Figure 5). The apparent first order degradation rate constant and the half life time at each temperature were calculated (Table 4). Plotting $\log \mathrm{K}$ values $v s$ 1/T,the Arrhenius plot [20] was obtained (Figure 6). The activation energy was calculated and found to be $14.75 \mathrm{~K} . J / \mathrm{mole}$ in case of alkaline degradation and $13.42 \mathrm{~K}$.J /mole in case of acidic degradation.These values are in accordance with the reported values for amide group [20]. It is postulated that the degradation process involve the amide linkage in both acidic and alkaline media (Figure 7).

\section{Stability}

The stability of the methanolic sample solutions at room temperature $\left(25^{\circ} \mathrm{C}\right)$ for 24 hour after preparation,was verified by reassaying them. There is no indication of any decomposition of idrocilamide in the samples for one week.

\section{Chromatographic performance}

Two defined symmetrical peaks were obtained upon measuring the UV response of the eluate under the optimum experimental parameters (Figure 6). Idrocilamide peak was obtained at retention time of $3.2 \mathrm{~min}$ and the degradation product at $1.5 \mathrm{~min}$.

\section{Conclusion}

The present investigation confirms that the use of micellar mobile phases in HPLC provides selectivity and separation efficiency comparable to conventional reversed phase HPLC systems for the determination of idrocilamide. The proposed method provides a stability indicating method for the determination of idrocilamide in presence of its degradation products offering additional advantages over comparison methods. The proposed method can be used in routine analysis of idrocilamide pharmaceutical preparations and biological fluids.

\section{References}

1. Susan B (1996) The Merck Index (12th edn) White house station, NJ: 4937.

2. Reynolds, L.E.F (2007) Matindale, The Extra Pharmacopoeia (35th edn) The Pharmaceutical Press, London: 49.

3. 3. Xu JF, Yang XG , Zhoo WJ, Zhao WJ ( 1993) Percutaneous penetration capacity of idrocilamide and HPLC determination of plasma concentrations. Zhongguo-Yaoxue-Zazhi 28: 4224-226.

4. Wang J, Xu J, Zeng S, Zheng X (1990) Zhongguo-Yiyao-Gongye-Zazhi 2: 467469 .

5. Salem M, El Din Salama N, Abd El-Halim L, Abdel Fattah L (2010) Use of validated stability-indicating chromatographic methods for quantitative analysis of idrocilamide in a pharmaceutical formulation. ActaChromatographica 22 569-579.

6. Maissa YS, Nahla, NS, Lobna MA, Laila SA (2009) Stability-indicating UV spectrophotometric methods for analysis of idrocilamide and veralipride in presence of their degradation products. Bulletin of the Faculty of Pharmacy (Cairo University) 47: 35-48.

7. Mei C, Devasish B, Josep E, Juan P, Maria R. et al.(2011) Determination of Putrescine and Tyramine in Fish by Micellar Liquid Chromatography with UV Detection Using Direct Injection. The Open Analytical Chemistry Journal 5: 2226.

8. Ruiz M, Carda S, Torres J, García M (2009) Retention mechanisms in micellar liquid chromatography. J. Chromatogr. A 1216: 1798-1814.

9. Esteve-Romero J, Samuel C, Maria R (2010) Micellar liquid chromatography in bioanalytical chemistry. Contribution to science 6: 105-114

10. Berthod A (1997) Causes and remediation of reduced efficiency in micellar liquid chromatography. J. Chromatogr. A 780: 191-206.

11. Dorsey JG, DeEchengaray MT, Landy JS (1983) Efficiency enhancement in micellar liquid chromatography. Anal Chem. 55: 924-928.

12. Thogchai W, Liawruangrath B (2013) Micellar liquid chromatographic determination of arbutin and hydroquinone in medicinal plant extracts and commercial cosmetic products. International Journal of Cosmetic Science 35: 257-263

13. Swati D, Devasish B, Shukla SK, Abhilasha Di, Esteve-Romero J (2013) Monitoring strychnine and brucine in biochemical samples using direct injection micellar liquid chromatography. Anal. Methods 5: 1747-1754.

14. Dalia R (2012) Simultaneous Determination of Metformin, Nateglinide and Gliclazide in Pharmaceutical Preparations Using Micellar Liquid Chromatography Int J Biomed Sci.(2) 8: 144-151.

15. Walash M, Metwally M, Eid M, El-Shaheny R ( 2010) Development and validation of micellar liquid chromatographic method for the determination of risedronate. J.AOAC.Int. 93: 1228-1235.

16. Belal F, EIBrashy A, Eid M , Nasr,JJ (2009) Stability-indicating micellar liquid chromatographic method for the determination of clopidogrel. J.Liq.Chromatogr. Relat.Technol. 32: 2993-3008.

17. Rizk M, Ibrahim F, Hefnawy M, Nasr JJ (2007) The analysis of benzyl alcoho and benzaldehyde in injectable formulations. Acta.Pharm. 57: 231-239

18. Miller JC, Miller JN, (1993) Statistics for Analytical Chemistry (4th edn) EllisHowood, NY: 115

19. Xu J, Li H, Zhao J , Liu S (1996) Pharmacokinetic studies of idrocilamide in normal volunteers and patients with spinal spasticity. Zhongguo-YiyaoGongyeZazhi 27: 503-505

20. Conner KA, Amidon GL (1979) Chemical Stabililty of Pharmaceuticals John Wiley and Sons, NY: 20 